\title{
Identifikasi Pemanfaatan Obat Herbal Pada Ibu Nifas
}

\author{
Citra Hadi Kurniati ${ }^{1}$, Atika Nur Azizah ${ }^{2}$ \\ 1,2 Universitas Muhammadiyah Purwokerto / citrahadi85@gmail.com
}

\begin{abstract}
ABSTRAK
Latar Belakang : Obat herbal merupakan obat yang berasal dari campuran bahan alami yang berbentuk ramuan dalam formulasi yang diinginkan. Penggunaan obat herbal sekarang sudah berkembang pesat dengan penggunaan bahan dari alam.

Penggunaan obat herbal ini dimanfaatkan tidak hanya untuk orang yang sakit, tetapi untuk pemulihan kesehatan misalnya pada ibu nifas. Kepercayaan yang turun temurun sehingga masih banyak yang menggunakan bahan tradisional dalam pengobatannya maupun pada perawatan masa nifas.

Tujuan : Mengetahui pemanfaatan obat herbal pada ibu nifas di wilayah kerja Puskesmas Cilongok 2 Kabupaten Banyumas.

Metode : Penelitian kualitatif dengan rancangan penelitian studi kasus (case study). Subjek penelitian ini yaitu ibu nifas, suaminya dan bidan desa. Analisis data dalam penelitian kualitatif ini menggunakan thematic content analysis.

Hasil : Jenis tanaman herbal yang digunakan pada ibu nifas yaitu kunyit, asam jawa, dan katuk.

Kesimpulan : Obat herbal dimanfaatkan oleh masyarakat karena faktor kepercayaan secara tradisional dan turun-temurun diperoleh dengan menanam sendiri tanaman herbal. Jenis tanaman herbal yang dimanfaatkan yaitu kunyit, asam jawa, dan katuk.
\end{abstract}

Kata Kunci : Obat herbal dan ibu nifas

\begin{abstract}
Background: Herbal medicine is a drug derived from a mixture of natural ingredients in the form of herbs in the desired formulation. The use of herbal medicine has now grown rapidly with the use of ingredients from nature.

The use of this herbal remedy is used not only for sick people, but for health recovery for example in postpartum mothers. Beliefs are hereditary so that there are still many who use traditional ingredients in their treatment and in the treatment of postpartum.

Purpose: Knowing the utilization of herbal medicine in mothers nifas in the working area of Puskesmas Cilongok 2 Banyumas Regency.

Method: Qualitative research with case study design. The subjects of the study were Nifas'mother, her husband and the village midwife. Data analysis in this qualitative research uses thematic content analysis.

Results: Types of herbal plants used in mother nifas are turmeric, tamarind, and katuk.

Conclusion: Herbal medicine is utilized by the public because the belief factor is traditionally and hereditary obtained by growing their own herbal plants. Types of herbal plants that are used are turmeric, tamarind, and katuk
\end{abstract}

Keywords: Herbal medicine and puerperal mothers

\section{PENDAHULUAN}

Indonesia memiliki keanekaragaman

digunakan oleh penduduk Indonesia

hayati yang dapat dimanfaatkan sebagai

bahan obat. Tanaman obat telah lama

sebagai pengobatan, baik untuk pencegahan penyakit, penyembuhan dan peningkatan derajad kesehatan. 
Kecenderungan sekarang juga bahwa masyarakat di Indonesia pola hidupnya kembali ke alam. ${ }^{(1)}$

Penggunaan obat herbal sebagai obat tradisional telah dilakukan oleh nenek moyang sejak berabad-abad yang lalu. WHO merekomendasikan penggunaan obat tradisional dalam pemeliharaan kesehatan masyarakat, pencegahan penyakit, dan pengobatan penyakit. Penggunaan obat tradisional dinilai lebih aman dari penggunaan obat modern karena memiliki efek samping lebih sedikit daripada obat modern ${ }^{(2)}$

Obat herbal sebagai bahan baku yang berasal dari tumbuhan diyakini tidak memiliki efek samping dan bermanfaat bagi kesehatan. Obat herbal bisa digunakan secara langsung maupun dengan pengolahan terlebih dahulu. Obat herbal tidak hanya digunakan di Indonesia tapi juga banyak dikembangkan di negara maju. Pemanfaatannya diyakini dapat meningkatkan usia harapan hidup, adanya kegagalan penggunaan obat modern, dan semakin meluasnya akses informasi obat herbal diseluruh dunia.

Obat herbal merupakan obat yang berasal dari campuran bahan alami yang berbentuk ramuan dalam formulasi yang diinginkan. Penggunaan obat herbal sekarang sudah berkembang pesat dengan penggunaan bahan dari alam. Herbal diklasifikasikan menjadi 3 kategori yaitu jamu, obat herbal dan fitofarmaka. Obat herbal dalam bentuk sediaan banyak dijual dimasyarakat umum tetapi ini belum terstandar (1)

Penggunaan obat herbal ini dimanfaatkan tidak hanya untuk orang yang sakit, tetapi untuk pemulihan kesehatan misalnya pada ibu nifas. Masa nifas / Postpartum merupakan masa setelah melahirkan dari plasenta lahir dan berakhir ketika alat - alat kandungan kembali seperti sebelum hamil sekitar 6 minggu. Asuhan masa postpartum sangat diperlukan karena termasuk masa kritis baik ibu maupun bayinya. Diperkirakan $60 \%$ kematian ibu akibat kehamilan terjadi setelah persalinan dan $50 \%$ kematian masa nifas terjadi dalam 24 jam pertama.

Perawatan pada masa nifas sangat penting karena bisa mendeteksi secara dini dan mengatasi komplikasi yang timbul pasca persalinan dan untuk memberikan informasi yang penting kepada ibu tentang cara merawat diri dan bayinya. Pada masa postpartum terdapat tiga proses perubahan penting yaitu masa pengecilan rahim (involusi), kekentalan darah dan masa laktasi atau menyusui (4)

Kepercayaan masyarakat di Jawa bahwa setelah masa melahirkan memanggil dukun untuk merawat dirinya maupun bayinya. Dukun melakukan pemijatan maupun memandikan bayinya sampai puput atau lepasnya tali pusat. Dukun bayi memberikan ramuan dalam bentuk jamu maupun yang dilumuri didalam tubuh ibu nifas.

Wilayah kerja puskesmas Cilongok 2 merupakan salah satu puskesmas di Kabupaten Banyumas dengan keadaan geografis yang berupa dataran tinggi. Di wilayah tersebut masih banyak dukun yang membantu ibu setelah bersalin seperti memijat ibu nifas dan memandikan bayi sampai puput tali pusatnya. Dukun bayi menganjurkan ibu minum jamu maupun dari orang tua ibu nifas tersebut. Masih banyak pedagang jamu di daerah tersebut. Kepercayaan 
yang turun temurun sehingga masih banyak yang menggunakan bahan tradisional dalam pengobatannya maupun pada perawatan masa nifas.

\section{METODE}

Penelitian ini menggunakan metode kualitatif dengan rancangan penelitian studi kasus (case study). Informan dipilih karena dianggap memiliki informasi yang cukup dengan kriteria inklusi. Pengumpulan data dilakukan dengan cara Wawancara mendalam (indepth interview), dokumentasi berupa catatan data-data dan foto penelitian, dan triangulasi.

Penelitian dilakukan di Desa Pekaja Kecamatan Kalibagor Banyumas. Pemilihan lokasi ini berdasarkan jumlah ibu nifas yang masih memanggil dukun bayi serta masih banyak pendudukan yg masih mengkonsumsi jamu. Analisis data dalam penelitian kualitatif ini menggunakan thematic content analysis.

\section{HASIL}

Hasil wawancara terhadap responden ibu nifas di Desa Jatisaba, Wilayah Kerja Puskesmas Cilongok 2 yaitu:

Pertama, minat pemanfaatan, responden pertama menunjukan adanya minat pada pemanfaatan tanaman herbal selama nifas dengan mengatakan "kalo setelah lahiran dikasih jaти пи dikasih sama mbah dukun, ndadak buat". Sama halnya dengan responden kedua "Pas bar lairan ya dikasih jamu tapi ya ga diminum terus soalnya takut ya kan sekarang udah dikasih obat dari puskesmas jadi ya minum obat aja", sama halnya dengan responden ketiga "ya itu minum jamu tapi ga diminum tiap hari kalau mau minum aja, udah dikasih obat kok". Responden keempat menunjukkan adanya minat terhadap tanaman herbal pada masa nifas "ini anak kedua juga ya minum jamu, makan katuk". Sama halnya dengan responden kelima "iya dikasih jamu untuk diminum setelah lahiran".

Kedua, alasan pemanfaatan, responden pertama "katanya kan buat uуub-uуub ASI". Responden kedua "Yaa udah borongan gitu lamar dari hamil sampe lairan sama mbah dukun sampe 7 hari tok". Responden ketiga "rata-rata setelah lairan ya pada minum jamu yang dibuatin mbah dukun, udah dari hamil dipegang soalnya". Responden keempat "udah dari lairan pertama ya minum jamu trus sama makan katuk terus". Responden kelima "ya masih mempertahankan dari keturunan ibu ya gitu".

Ketiga, jenis tanaman herbal, Responden pertama mengatakan "kunir iya minum kunir". Hampir sama dengan Responden kedua yang mengatakan "minumnya kunir tapi kaya ada asemasemnya palingan ya dicampur asem". Hal sama disampaikan oleh responden ketiga "kunir asem itu pastinya". Sedangkan responden keempat mengatakan "biasa dikasih kunir asem...makan katuk terus". Sama halnya dengan responden kelima yang mengatakan "pakenya pasti kunir asem kalau setelah lairan".

Keempat, cara pemanfaatan, responden pertama mengatakan bahwa cara pemanfaatan kunyit "diminum selama 7 hari tapi ga setiap hari dikasih gitu sekitar tiga kali dikasihnya satu gelas belimbing tapi lebih gede,ga tau buatnya jadi ya langsung diminum". Responden kedua yang menggunakan kunir asem "kunyit ya enten asem tujuh hari doang setiap hari dikasih, satu gelas doang". Responden 
keempat yang menggunakan kunir asem gula, "kunir kalih asem ngangge gula jawa sampun digodog teng mriko gene mbah dukun, makan daun katuk gih daun-daun yang muda niko didamel beningan dados enak". Responden kelima yang menggunakan kunir "kunir 3 ruas dibebek rihin teras digodog gih sari ne diunjuk".

$$
\text { Kelima, sumber perolehan, }
$$
responden pertama mengatakan bahwa sumber perolehan obat herbal dari dukun "langsung dikasih dari mbah dukun", sama halnya dengan responden kedua "owh ya dari mbah dukun, ga bikin sendiri tapi kalau Mandan kurang seger ya dikasih asem sendiri..kan ada dirumah biasa beli". Begitu pula dengan responden keempat "mbah dukun yang mbuatin jamunya.. nek beningan katuk gih damel piyambek niko teng emper kathah". Responden kelima sama juga mengatakan hal yang sama "kalo disini ya udah terima beres dari mbah dukun langsung dibuatin fresh gitu, tapi ya Cuma enam hari aja setelahnya ya buat sendiri kan nanem dibelakang rumah banyak kunirnya".

Keenam, pengetahuan tentang pemanfaatan obat herbal. Responden pertama mengatakan tentang pengetahuannya pada pemanfaatan obat herbal dari keluarganya "pake jamu ya taunya dari ibu katanya kan buat uyubuyub ASI tapi ya seger". Namun untuk responden kedua mengetahui tentang obat herbal secara turun temurun dari orangtua "Jaman dulu kan suruh minum kunir asem biar ASInya lancar". Sama halnya dengan responden ketiga, keempat, dan kelima. Responden ketiga mengatakan "udah dari dulu pake jamu turun temurun". Responden keempat mengatakan "percaya dari awal hamil sampe yang kedua ini banyak manfaatnya badannya jadi kepenak kan dipijet juga, nek daun katuk ya ngelancarin ASI ". Dan responden kelima mengatakan "taunya sekang mamake, ganu mboten enten obat-obatan dados sering ndamel piyambek".

Tabel 1. Jenis-jenis tanaman herbal yang dimanfaatkan oleh Responden.

\begin{tabular}{lllll}
\hline No. & $\begin{array}{c}\text { Nama } \\
\text { Tanaman }\end{array}$ & $\begin{array}{c}\text { Bagian Yang } \\
\text { Digunakan }\end{array}$ & Sumber Perolehan & \multicolumn{1}{c}{ Cara Penggunaan } \\
\hline $\mathbf{1}$ & Kunyit & Umbi & $\begin{array}{l}\text { Dukun } \\
\text { Tanam sendiri }\end{array}$ & $\begin{array}{l}\text { Kunyit ditumbuk kemudian direbus dan } \\
\text { diambil sarinya }\end{array}$ \\
\hline $\mathbf{2}$ & Asem Jawa & Buah & $\begin{array}{l}\text { Dukun } \\
\text { Beli langsung }\end{array}$ & $\begin{array}{l}\text { 1. Dicampurkan dengan kunyit } \\
\text { 2. Asem dicampurkan dengan kunyit dan } \\
\text { diberi gula merah }\end{array}$ \\
\hline $\mathbf{3}$ & Katuk & Daun & Tanam sendiri & $\begin{array}{l}\text { Daun katuk direbus dibuat sup untuk } \\
\text { dikonsumsi }\end{array}$ \\
\hline
\end{tabular}

\section{PEMBAHASAN}

Berdasarkan hasil penelitian terhadap responden tentang minat pemanfaatan tanaman herbal, alasan pemanfaatan, jenis tanaman herbal, cara pemanfaatan sumber perolehan, dan pengetahuan tentang pemanfaatan tanaman herbal pada ibu nifas. Triangulasi juga dilakukan pada salah satu Bidan Desa di Wilayah Kerja Puskesmas Cilongok 2 : 
"Masih banyak yang pakai jamu kalau untuk nifas, mbah dukun masih membuatkan jamu, tapi kalau orang muda ya ada yang udah males yaa tapi udah dikasih tau dengan mbah dukun lebih baik membuat jamu sendiri daripada beli. Saya kasih tau juga untuk jarak minum jamu dengan obat yaa 2 (dua) jam. Pemberian jamu selagi tidak merugikan, belum ada larangan dari dinas, untuk ibu nifas yaa..bukan ibu hamil. Pakainya kunir sama asem, itu combain ada unsur asemnya tapi itu sedikit. Aku berfikir kalau kunir itu ada antiseptiknya. Selama ini ga ada yang mengeluh setelah minum jamu untuk produksi ASI nya, kecuali kalau yang disesar yaa.. "

Berdasarkan hasil wawancara yang dilakukan, tidak semua responden memiliki tingkat pengetahuan yang berbeda mengetahui manfaat dari pemanfaatan tanaman herbal pada ibu nifas, mereka hanya menggunakan tanaman herbal karena tanaman yang digunakan merupakan digunakan turun temurun yang masih dilestarikan hingga sekarang. Ada juga responden yang mengetahui manfaat dari tanaman herbal, karena mereka juga merasakan sendiri manfaat tersebut.

"Jaman dulu kan suruh minum kunir asem biar ASInya lancar" (RES.2)

Hal ini diungkapkan juga oleh WHO 2002 dalam Ricther peracikan obat tradisional dilakukan berdasarkan tradisi (turun temurun) sehingga bentuk pengobatan tersebut masih terjaga hingga saat ini. Pengobatan tradisional mencakup elemen dan karakteristik yang luas, sperti praktik kesehatan, pendekatan, pengetahuan, dan kepercayaan, yang menggabungkan pengobatan dengan menggunakan tanaman dan terapi-terapi spiritual, yang dibuat berdasarkan pengalaman serta cara-cara manual (tradisional) yang diturunkan dari generasi ke generasi.

Hasil wawancara dengan beberapa responden, ditemukan bahwa ibu yang membuat tanaman herbal dengan takarannya adalah dengan beberapa ruas. Takaran untuk mengkonsumsi obat tersebut ada yang mengkonsumsi obat tradisional dengan takaran gelas dan ada juga yang satu gelas.

"diminum selama 7 hari tapi ga setiap hari dikasih gitu sekitar tiga kali dikasihnya satu gelas belimbing tapi lebih gede, ga tau buatnya jadi ya langsung diminum" (RES.1)

Adanya aturan dalam penggunaan obat tradisional dapat didasarkan pada pengalaman dari nenek moyang yang menyampaikan informasi penggunaan pengobatan nifas kepada keturunannya. Hal ini dilakukan oleh nenek moyang terdahulu yang bisa merupakan sebuah bentuk trial and error, dengan dosis atau penggunaan yang berlebihan justru dapat membahayakan. Inilah yang disebut oleh Ngatimin sebagai imperical behaviour, perilaku yang didapatkan karena pengalaman. Ngatimin menambahkan bahwa dari pengalaman perilaku inilah diperoleh manfaat bahwa trial and error merupakan bagian dari pola hidup sehat masyarakat. (6)

Hasil penelitian ini mendukung kepercayaan masyarakat bahwa jamu dapat memperlancar ASI. Perilaku positif yang masih dijalankan oleh sebagian besar ibu nifas dari Suku Jawa setelah melahirkan 
yaitu kebiasaan minum jamu dengan tujuan agar ASI mereka lancar serta untuk menjaga kesehatan dan kebugaran ibu. Jamu diminum agar ASI lancer. (7) (8)

Berdasarkan hasil penelitian tentang jenis tanaman herbal yang digunakan responden yaitu kunir

"kunir iya minum kunir" (RES.1)

Jamu merupakan ramuan tradisional dengan cara ditumbuk dan direbus airnya. Jamu ini dipercaya dapat memperlancar produksi ASI. Khasiat jamu untuk memperlancar ASI ini, bila dilihat dari bahan-bahan yang digunakan antara lain: kunyit mengandung senyawa kimia yang disebut kurkuminoid (kurkumin, desmetoksi-kumin, dan bisdesmetoksikurkumin). Kunyit juga mengandung minyak atsiri yang dapat meningkatkan produksi ASI.

Jenis tanaman herbal yang digunakan responden yaitu Asem jawa.

"minumnya kunir tapi kaya ada asem-asemnya palingan ya dicampur asem" (RES.2)

Asem jawa mengandung Kalori, Protein, Lemak, Hidrat arang, Kalsium, Vitamin A, Vitamin B1, Vitamin C. Asem Jawa karena banyaknya kandungan kimiawi yang ada di dalamnya, maka asam jawa dapat digunakan untuk menyembuhkan berbagai penyakit seperti asma, batuk, demam, sakit panas, rematik, sakit perut, morbili, alergi (biduren), sariawan, luka baru, luka borok, eksim, bisul, bengkak karena disengat lipan atau lebah, gigitan ular berbisa, dan rambut rontok. Dilihat dari manfaatnya asam jawa dapat menjaga kesehatan fisik ibu nifas, kesehatan fisik ibu merupakan salah satu faktor yang dapat mempengaruhi produksi ASI. (9)

Jenis tanaman herbal yang digunakan responden yaitu daun katuk.

"biasa dikasih kunir asem...makan

katuk terus" (RES.4).

Daun katuk memiliki kandungan protein, lemak, kalsium, posfor, besi, vitamin $\mathrm{A}$, vitamin $\mathrm{B} 1$, vitamin $\mathrm{C}$. Kandungan gizi daun katuk adalah kandungan steroid dan polifenol yang bisa membantu untuk meningkatkan kadar prolaktin. Kadar prolaktin yang sangat tinggi ini akan membantu untuk meningkatkan, mempercepat dan juga melancarkan produksi ASI. (10)(11)

\section{KESIMPULAN}

Kesimpulan penelitian "pemanfaatan obat herbal pada ibu nifas Di Wilayah Kerja Puskesmas Cilongok 2 Kabupaten Banyumas" yaitu berdasarkan minat pemanfaatan tanaman herbal, alasan pemanfaatan, jenis tanaman herbal, cara pemanfaatan sumber perolehan, dan pengetahuan tentang pemanfaatan tanaman herbal pada ibu nifas. Jenis tanaman herbal yang digunakan yaitu kunyit, asam jawa, dan katuk.

\section{SARAN}

Obat herbal dimanfaatkan oleh masyarakat karena faktor kepercayaan secara tradisional dan turun-temurun sehingga tenaga bidan perlu memberikan pendidikan kesehatan terkait pemanfaatan obat herbal pada ibu nifas.

\section{DAFTAR PUSTAKA}


1. Hernani. Pengembangan Biofarmaka Sebagai Obat Herbal Untuk kesehatan. Bul Teknol Pascapanen Pertan. 2011;7(1).

2. Lusia O. Pemanfaatan Obat Tradisional Dengan Pertimbangan Manfaat dan Keamanannya. Jember. Maj Ilmu Kefarmasian. 2006;III(1):01-7.

3. Hidayat M. Obat Herbal (Herbal Medicine) : Apa Yang Perlu Disampaikan Pada Mahasiswa Farmasi dan Mahaiswa Kedokteran? Pengemb Pendidik. 2006;3(1):141-7.

4. Saleha S. Asuhan kebidanan Pada Masa Nifas. Jakarta: Salemba Medica; 2009.

5. Ricther M. Tradisional Medicines And Tradisional Healers In South Africa [Internet]. AIDS Law Project. 2013 [cited 2013 Nov 5]. Available from:

http://www.tac.org.za/Documents/ReasearchPapers/Tradisional_Madicine_Briefing.pdf ;2017

6. Notoadmodjo. Promosi Kesehatan Teori dan Aplikasi. Jakarta: Rineka Cipta; 2015.

7. Yuliyanti L. Gambaran Perawatan Ibu Nifas di Wilayah Kecamatan Miri Sragen. UNIVERSITAS MUHAMMADIYAH SURAKARTA; 2014.

8. Suryawati C. Faktor Sosial Budaya dalam Praktik Perawatan Kehamilan, Persalinan dan Pasca Persalinan (Studi di Kecamatan Bangsri Kabupaten Jepara). J Promosi Kesehat Indones Indones. 2007;2(1).

9. Rasy V. Tanaman Herbal Untuk Pengobatan Tradisional. Sakti. Yogyakarta; 2013.

10. Subagya HP. Kitab Ramuan Tradisional Dan Herbal Nusantara. Yogyakarta: Laksana; 2013.

11. Usemahu K, Rchman W, Natsir S. Perilaku Penggunaan Obat Tradisional Pada Ibu Pasca

Melahirkan Di Desa Kailolo Kabupaten Maluku Tengah. FKM Universitas Hasanudin; 2014. 